\title{
Embedded Identities and Dialogic Consensus: Educational implications from the communitarian theory of Bhikhu Parekh
}

\author{
Michael S. MerRY
}

Beloit College, Wisconsin

\begin{abstract}
In this article the author will investigate the extent to which Bhikhu Parekh believes that a person's cultural/religious background must be preserved and whether, by implication, religious schooling is justified by his theory. His discussion will explore-by inference and implication - whether Parekh's carefully crafted multiculturalism, enriched and illuminated by numerous practical insights, is socially tenable. The author will also consider whether, by extension, it is justifiable, on his line of reasoning, to cultivate cultural and religious understandings among one's own children. Finally, the author will contend that Parekh, notwithstanding his cautious, even-handed approach, commits several important errors, including conflating the culture of the parents with that of the children and insisting that cultural and religious persons ought to be allowed to defend their views in the public square on religious grounds.
\end{abstract}

Keywords: Culture, liberalism, religion, cosmopolitanism, diversity, dialogue

The only choice open to any society today is to manage and build on the creative potential of its diversity.

-Parekh, Rethinking Multiculturalism, p. 171

Bhikhu Parekh, a member of the British House of Lords and a leading interpreter of political theory, defends the objective good of cultural diversity and embraces a tolerance of difference, critical self-consciousness, empathic understanding and intellectual openness. He argues that individuals have to be understood in both a particular as well as a universal sense. The particular sense is cultural (and this includes religion $)^{1}$ and Parekh is convinced that each of us, while not determined by culture, is nevertheless embedded in culture. To put a finer point on it, culture is constitutive of who we are, for cultures not only locate us according to particular contexts, they affect us deeply and irrevocably to the point of structuring and shaping our very personalities and providing the content of our identities. Conversely, the universal sense in which human beings must be understood appeals to 
a code of human rights that can be derived from intercultural exchange and which seeks to build consensus through mutual respect and understanding. To emphasize one aspect to the exclusion of the other is to court a myopic understanding of the human person.

Parekh does not justify all human behavior in terms of each individual's culture or value system. Nevertheless, Parekh seeks to challenge liberalism, broadly conceived, and its singular stress on cultivating individual autonomy, rationality, and its instrumental view of culture. As an alternative to liberalism, he endorses multiculturalism. Multiculturalism, to quote Parekh at some length,

... deflates the absolutist pretensions of liberalism and requires it to acknowledge its contingent historical and cultural roots. Since no culture exhausts the full range of human possibilities, multiculturalism also requires liberalism to become self-critical and to engage in an open-minded dialogue with other doctrines and cultures. It rejects the liberal claim to enjoy the monopoly of moral good and to be the final arbiter of all moral values, its crude and tendentious division of all ways of life and thought into liberal and nonliberal, and its persistent tendency to avoid dialogue with other cultures by viewing them as nothing more than minority cultures whom it would 'grant' such rights as it unilaterally determines. (Parekh, 1999, p. 74)

Parekh is wholeheartedly multiculturalist inasmuch as he aims to affirm the identities that persons inherit; but he possesses familiar liberal traits as well, for we hear him call upon individuals to critically evaluate their views, engage the perspectives of others, and be open to revising one's opinions. Yet it would be more accurate to call Parekh a communitarian, though one could also label him a multicultural liberal. Ever mindful of the reality of pluralism, Parekh attempts to build on the creative potential of cultural diversity in a new and interesting way.

In this paper, my discussion will investigate the extent to which Parekh believes that a person's cultural/religious background must be preserved and whether, by implication, religious schooling is justified by his theory. My discussion will explore-by inference and implication-whether Parekh's carefully crafted multiculturalism, enriched and illuminated by numerous practical insights, is socially tenable. I will also consider whether, by extension, it is justifiable, on his line of reasoning, to cultivate cultural and religious understandings among one's own children. I will contend that Parekh, notwithstanding his cautious, even-handed approach, commits three important errors of increasing severity:

- He insists that cultural and religious persons ought to be allowed to defend their views in the public square on religious grounds.

- He exaggerates the degree to which persons are incapable of transcending their culturally embedded values.

- He conflates the culture of the parents with that of the children.

By insisting that cultural and religious minorities should be given the right to blend their private and public lives in the political deliberative process, Parekh wishes to 
resist the liberal habit of abstracting away from one's most cherished beliefs in order to arrive at a reasonable consensus vis-à-vis the public good. Though Parekh makes a strong case for incorporating religious arguments into the political deliberative process, I will disagree with Parekh and argue that the separation of public and private concerns is both politically expedient and wise. When I say that he exaggerates the sense in which persons are incapable of transcending their culturally embedded values, I will show that Parekh draws a very tight link between a person's cultural background and the person that she becomes or is capable of becoming.

While Parekh acknowledges that persons may-and indeed ought to-question their cultural practices, he does not accept the view that autonomy divorced from one's particular history, geography and family context is possible. 'Autonomy,' he writes, 'is difficult to define and impossible to measure or demonstrate, and any attempt to violate equality in its name opens the door to all manner of specious reasoning ...' (Parekh, 2000, p. 253). I assert that Parekh conflates the culture of the parents with the culture of the children, and makes no fine distinction between the cultural pursuits of the parents and those that are passed down-one could say, imposed - on one's children. This point is particularly important when we come to the question of religious schooling and the right of parents to sequester their children-even in the privacy of their own homes-for comprehensive cultural and religious education. Ultimately, I will argue, Parekh's theory provides a powerful rationale for advocates of parents' rights to educate their children as they see fit. If, the argument may run, parents are culturally embedded and need to have an adequate understanding of their cultural and/or religious identities in order to flourish, then they are justified in sending their child(ren) to comprehensive (e.g., Jewish, Islamic, Sikh, Evangelical Protestant) religious schools that aim to provide children with the ethnic/religious (ethnicity being more relevant in some traditions than others) content specific to the parents' worldview.

Before I elaborate each of these points, I will first sketch Parekh's main ideas.

\section{Cultural Embeddedness}

Parekh engages his reader in a sophisticated and enlightening discussion on the differences between society and culture, as well as the differences between culture and religion. Culture, for Parekh, is:

... a historically created system of meaning and significance [ ... ] a system of beliefs and practices in terms of which a group of human beings understand, regulate and structure their individual and collective lives. It is a way of both understanding and organizing human life. (Parekh, 2000, p. 143)

And elsewhere, elucidating the role of culture in our lives, he adds,

... our culture gives coherence to our lives, gives us the resources to make sense of the world, stabilizes our personality, and so on. Its values and ideals inspire us, act as our moral compass, and guide us through life; its 
arts, rituals, songs, stories and literature fill us with joy and add colour and beauty to our lives; and its moral and spiritual wisdom comforts and helps us cope with the inevitable tragedies of life. (ibid., p. 159)

Parekh recognizes that cultures are far from static and develop over time; he affirms that cultures must adapt and change if they are to avoid dying out. Moreover, he is mindful of the fact that no culture is undifferentiated or univocal but contains a variety of interpretive strains within it. This means that no one's cultural identity is ever settled or fixed for all time, for new situations and knowledge (e.g., technology, conquests, and natural calamities) necessitate an ongoing reevaluation of culture. ${ }^{2}$

In articulating his understanding of culture, Parekh is careful to avoid two extremes. On the one hand, he tries to avoid a monist tendency, which attempts to reduce cultures to their trans-cultural essence. Drawing upon the work of Isaiah Berlin, Parekh contends that moral monism:

... either argues that one value is the highest and others merely a means to or conditions of it, or more plausibly and commonly that although all values are equally important or some more than others, there is only one best or truly rational way to combine them. For the monist evil, like error, can take many forms, but the good, like truth, is inherently singular or uniform in nature. (ibid., p. 16)

Parekh charges that monists frequently assume the superiority of certain cultures and thus conclude that it is acceptable to impose specific cultural values on others. ${ }^{3}$ But Parekh also tries to avoid the culturalist tendency. Culturalists make the opposite mistake, Parekh continues, by maintaining that, since cultures have a right to exist and be protected, there is no room for criticism or judgement towards cultures for the values, beliefs and practices that they embody. According to Parekh, both of these tendencies must be denied ontological privilege. 'No single value trumps all others,' he writes, 'and their relative importance can only be decided in the light of the social and cultural context and the likely consequences' (ibid., p. 320). He attempts to occupy a mediating space between these two realities.

Here Parekh comes very close to the views of Will Kymlicka. Both Parekh and Kymlicka emphatically deny liberals the right to impose their views on illiberal national minorities and both encourage dialogue as a way to reach respectful compromises. ${ }^{4}$ Both Parekh and Kymlicka also defend culture not in itself but insofar as it (a) firms up individual or group identities and bestows a sense of belonging, and (b) enhances personal agency and development, situating individuals in a framework within which one can make moral choices (Kymlicka, 1995, 83). ${ }^{5}$ All of these elements mean that culture is central to a person's well-being. Nevertheless, Kymlicka makes his position, pace Parekh, very explicit concerning his objection to communitarianism. Defending the liberal position, he writes,

If we wish to defend individual freedom of conscience, and not just group tolerance, we must reject the communitarian idea that people's ends are fixed and beyond rational revision. We must endorse the traditional liberal belief in personal autonomy. (Kymlicka, 1995, p. 163) 
Parekh objects to Kymlicka's emphasis on the centrality of autonomy and his insistence that a person's views should (or even can) be open to revision. ${ }^{6}$ As I explained earlier, Parekh has a fluid understanding of culture, but this does not prevent him from overplaying the sense in which we are necessarily shaped by our cultures. Having a 'deep bond' to our cultures, as Kymlicka would have it, is far different from the conclusion that Parekh draws from it.

\section{Culture, Cosmopolitanism and Coercion}

When Parekh describes individuals who are 'culturally footloose,' as he puts it, and appear to move effortlessly between different cultural milieus owing to an absence of loyalty to any one particular culture, he treats this as an undesirable deviation. Eclectic individuals who exchange and borrow from a variety of cultural repositories are likely to lead shallow and fragile lives, he claims. Cosmopolitans, he says, lack 'historical depth' and a sure foundation in a particular culture, are unlikely to have the resources necessary to negotiate their way in life. He believes that cosmopolitans are bereft of the moral compass that a disciplined life in one culture can provide. Parekh strips cosmopolitans of cultural identity altogether when he says, for instance, that their lives become 'a culture of quotations, a babble of discordant voices, and not a culture in any meaningful sense of the term'. Even though he recognizes that cultural boundaries must be stretched and tested, Parekh is convinced that individuals must find their bearings inside of structured boundaries, the absence of which provides no point of reference for making meaningful decisions.

Parekh is also aware of the coercive role that culture may play in the lives of individuals, particularly the way that it institutionalizes, exercises and distributes power'. Cultural values are often arrived at and acquire their dominant position 'through a prolonged process of indoctrination and coercion, and continue to be actively or passively contested by marginalized groups' (Parekh, 2000, p. 268). Nevertheless, he is convinced that individuals are resourceful enough to obtain critical distance from their cultural bearings. Here Parekh takes a step back from his previous assertiveness concerning the constitutive role of culture and argues that no one is so pliant as to be subject to cultural restraints without a capacity to criticize, question and refuse the pressure to conform unthinkingly. To love one's culture, he says, is to wish it well, and 'that involves criticizing and removing its blemishes'.

But this ability of individuals to be self-critical and aware of the coercive elements of one's culture co-exists with his resolve that each person ought to feel loyalty to his or her culture 'because of its profound contribution to our lives and also perhaps because of its universal value' (ibid., p. 160). Parekh concedes that one's cultural loyalty may be overridden if one's judgement of it is overwhelmingly negative, but this seems a passing notion to which he gives no serious thought. Indeed, loyalty to the valuable aspects of one's culture is paramount to the point of it being a duty. Listen to Parekh:

We also have a duty to preserve and pass on to succeeding generations what we think valuable in it, to defend it against its perverse 
misrepresentations [ ... ] and to protect it against wanton attempts to destroy or discard it. (ibid.)

Parekh also claims that one's relationship to a cultural community is qualitatively different from one's relationship to voluntary associations. Voluntary associations are elective, he alleges, while cultural communities are inherited. 'Unlike voluntary associations we are deeply shaped by our cultural communities and derive our values and ideals from them,' he writes. A cultural community:

... performs a role in human life that a voluntary association cannot. It gives its members a sense of rootedness, existential stability, and feeling of belonging to an ongoing community of ancient and misty origins, and ease of communication. And it does all this only because it is not a conscious human creation and one's membership [to] it is neither a matter of choice nor can [it] be easily terminated. (ibid., p. 162)

The apparent inconsistencies in Parekh's notion of cultural rootedness, one that requires clear boundaries with historical depth while also admitting to a cross fertilization and lack of fixity, is an interesting via media, one that avoids the trappings of an essentialist notion of culture while embracing some aspects of cosmopolitanism. Parekh admits that isolated cultures are ill equipped to provide the resources necessary for critical engagement with difference and, owing to their homogeneous structure, often lead to feelings of powerlessness or confusion. Still, he does not hesitate to label cosmopolitanism as little more than the stuff of one's 'intellectual environment'. He does not give a convincing reason why a person might begin to order her life not according to her 'collective culture' but, rather, according to thoughts and habits inspired by the broad and sundry range of influences that Parekh relegates to the bewildering category of 'an unincorporated alien resource'. He does not explain exactly why one should be dismissive of a hybrid identity informed by an amalgam of influences but only argues that cultural communities create a dialectical space from within which we come to engage the world around us.

\section{An Argument for Diversity}

In order to appreciate the emphasis that Parekh places on cultural diversity, it is necessary to elaborate his argument defending diversity as an objective good. Diversity is no incidental feature of cultures or persons who inhabit them but constitutes a range of important goods that are desirable to members of a culture and non-members alike. Traditionally there have been those who have argued for the good of diversity for reasons such as (a) it expands the available range of options as well as the concomitant freedom of choice; (b) diversity is an unavoidable outcome of a person's 'right to culture'; (c) diversity provides the aesthetic benefit of a more rich and interesting cultural space from which one can reflect and create; and (d) diversity creates a healthy competitive atmosphere that prevents any one view from illegitimately dominating others. 
Parekh shows his appreciation for each of these reasons but ultimately finds them either shallow, vague, or insufficient. In their place, he provides his own reasons for valuing diversity per se:

Since human capacities and values conflict, every culture realizes a limited range of them and neglects, marginalizes and suppresses others. However rich it might be, no culture embodies all that is valuable in human life and develops the full range of human possibilities. Different cultures thus correct and complement each other, expand each other's horizon of thought and alert each other to new forms of human fulfillment. The value of other cultures is independent of whether or not they are options for us. Indeed they are often valuable precisely because they are not. Its inassimilable otherness challenges us intellectually and morally, stretches our imagination, and compels us to recognize the limits of our categories of thought. (ibid., p. 167, emphasis added)

Parekh links this awareness of cultural otherness to human freedom and stresses that, without alternative ways of imagining one's life, there would inevitably be a kind of determined confinement to one's inherited culture with no recourse to other ways of organizing and understanding human existence. Because diversity provides us with the means of self-knowledge and self-criticism, it is an objective good.

Parekh anticipates objections from those who claim to be content with their homogeneous cultures. Happy and satisfied with the network of relations and cultural norms of their own community, some will argue that they see no intrinsic benefit to diversity, especially when no culture contains the fullness of truth. Hence to engage in intercultural dialogue is to cast doubt on the value of following one's already fully valued way of life. Parekh acknowledges the strengths of a homogeneous society but nevertheless points out that '[E]ven when his culture is reasonably rich, such a dialogue [with other cultures] deepens his insight into it and helps him identify, nurture and exploit its resources better' (ibid., p. 171). Parekh steadfastly affirms the objective good of encountering diversity given the tendency of homogenized communities to 'become closed, intolerant, averse to change, claustrophic and oppressive, and to discourage differences [and] dissent' (ibid., p. 170). He insists that openness to diversity can benefit even relatively homogeneous cultures (though he would have to admit that benefiting from diversity is not guaranteed; nor should it be assumed that 'open cultures' naturally result in a manifest display of historical or conceptual depth necessary to sustain civic coherence).

\section{Liberalism and Dialogical Consensus}

Parekh knows that whatever the faults of liberalism, it remains the most congenial theory to cultural diversity. $\mathrm{He}$ is also aware that his liberal opposition to closed communities is as strong as it is precisely because he knows that tolerance, critical self-consciousness and intellectual openness are important moral virtues to cultivate. Parekh also affirms central liberal values when he says that treasuring cultural 
diversity is not synonymous with preserving 'prevailing forms' of domination or oppression, particularly when the cultural expression of domination or oppression does not command the allegiance of all members of a particular culture. His qualifying remarks are very timely here:

... all existing cultures need radical changes because of their deep-seated sexist, racist and other biases which cause considerable suffering to large sections of their members. Every age also has its distinct needs, experiences and aspirations, and cultures must be adapted to these if they are to conduce to human flourishing. (ibid., p. 169)

Therefore, insofar as Parekh argues for respect for culture, he does so only to the extent that the lives of its members are strengthened and enhanced. For example, he contends that, no matter what the custom, 'children should not be subjected to irreversible harm and women should be treated equally with men' (ibid., p. 294). Appealing to universal values as a basis for moral claims is valid and appropriate in many contexts and should be encouraged, he notes, but universal values cannot simply replace local values; they must be interwoven and interpreted in light of local values and norms in order to merit the attention and respect they rightly deserve. This is because individuals are 'not abstract moral beings,' Parekh insists, but are culturally constituted in particular ways. Parekh notes that a culture has its values to begin with:

... because society cherishes, endeavors to live by, and judges its members' behavior in terms of them. They are public because they are embodied in its constitutional, legal and civic institutions and practices and regulate the public conduct of its citizens. And the values are operative because they are not abstract ideals but are generally observed and constitute a lived social and moral reality. (ibid., p. 269, emphasis added)

That is to say, values lose much of their meaning if left to abstract devices dissociated from 'the procedures and practices in which they are embodied'. However, to reiterate, these values are not static but change according to societal circumstances and members' self-understanding. And, of course, there will always be those who dissent from the publicly recognized view. Parekh is correct to stress that, even in liberal democracies, there are many citizens who do not privately adhere to certain public virtues (e.g., equality, tolerance), but, owing to the moral coercion of public policy and sentiment, such citizens are constrained to behave in certain ways. This will play out differently for different people; for some, they will come to internalize the more tolerant attitudes that society comes to embrace while others will experience a separation between their public and private behavior.

Finding the resources to criticize cultures appropriately, Parekh insists, can usually be done from the inside. The internal resources necessary to challenge the prejudices within one's culture are possible because cultures have no essence but contain different strands of thought. In every cultural tradition, reformers have engaged in a hermeneutical struggle by highlighting those elements that have historically been marginalized or suppressed. Yet, because humans are incorrigibly 
prone to misjudgement, partiality and bias, authoritarian power structures frequently remain in place that thwart any and all attempts to question misapplications of cultural norms from the inside. The resources needed to properly evaluate cultures, then, must surpass the moral compass internal to cultural communities. But liberal universal values, Parekh adds, must also be interpreted, adjusted and local circumstances must be 'related to the moral and cultural structure of the society concerned; in short, contextualized if they are to carry conviction' (ibid., p. 293).

Parekh issues a stern warning against the liberal tendency to judge cultures according to a handful of criteria. Liberal values such as autonomy, rationality and freedom are not reducible to a single standard unconnected to specific contexts. Parekh avers that comparing whole cultures on a single scale is 'logically incoherent' and that all cultures are in some sense incommensurable. He also declares that universal values depend on local circumstances if they are to retain 'their relevance, meaning and effectiveness'. Parekh adduces many examples to demonstrate his point, but none is more effective than the issue of headscarves for Muslim girls and women. Many Muslim women, as a BBC report (September 29, 2003) from Egypt recently indicated, regard their headscarves as a mechanism for freedom and mobility. Ethnographers in Dearborn, Michigan, have also noted that:

The Arabic girl has different ways to express her Arabic culture. Instead of a tattoo, her emblem is likely to be the 'cover' the local name for the hijab. It is as much a fashion statement as it is a religious one. Traditionally, the hijab is supposed to be a display of modesty in one's appearance. However, in the hands of the Arabic female, it becomes something else. ${ }^{7}$

Therefore, to see the headscarf merely as a sign of oppression is not only to lapse into crude stereotypes but also to fail to appreciate the complex process of negotiation and compromise that it entails. What is important to note here, then, is that religious or cultural symbols cannot be defined and compared in the abstract. This is, Parekh explains, both 'because they rarely have exactly equivalent significance and because they acquire different meanings in different contexts and historical periods and might sometimes even cease to be religious in nature'. ${ }^{8}$

\section{Comparative Evaluation and Political Deliberation}

Comparative evaluations as a way of appraising the moral value of certain cultural practices must be weighed against certain basic values such as respect for persons, personal choice, and basic human dignity. Yet even these basic values will be culturally mediated, Parekh purports, and one must not equate their import with some universal, context-free meaning. He explains his view this way:

... if a cultural community respects human worth and dignity, safeguards basic human interests within the limits of its resources, poses no threat to outsiders and enjoys the allegiance of most of its members, and thus provides the basic conditions of the good life, it deserves to be respected and left alone. (ibid., p. 177) 
There are reasons to be concerned here. For starters, Parekh does not define 'human worth and dignity' explicitly according to any recognizable standard (though he does appeal to the UN Charter as a fine approximation). Also, phrases such as 'poses no threat to outsiders' and 'enjoys the allegiance of most of its members' give little consideration to the welfare of minority members of these communities, including those who dissent from the majority view. Parekh acknowledges structured inequalities within cultures but believes that intercultural dialogue and reasoning, no matter how emotionally taxing, will provide the comparative basis for compelling change where interlocutors disagree with the cultural practices of others. He seems to believe that judgements of other cultures should be sympathetic to the particular thought patterns that inhere in a culture and insists that there can be no room for liberal unilateralism. This is because intercultural and political dialogue rarely occur between equals owing to prevailing structural disadvantages and economic inequalities. But Parekh does not hesitate to add:

$\ldots$ if after careful consideration and listening to their defense we find their choices perverse, outrageous or unacceptable, we have no duty to respect and even a duty not to respect these choices. We separate the right and its exercise, and do not allow our attitude to one to influence that to the other. Their right does not forfeit our respect because it is exercised badly, and our respect for it does not entail respect for its manner of exercise. (ibid., p. 176)

Using several concrete examples, Parekh demonstrates through sound reasoning how many controversial practices (e.g., female circumcision, sati or widow burning, polygyny) are not sustainable practices in view of their violation of basic human freedoms. For Parekh, respect for any culture will be based on how we assess its content; in particular our respect will be contingent on the life that is either provided for or denied to its members.

Political deliberation is the process whereby comparative intercultural evaluation for public policy can be achieved. Parekh calls for 'new institutional forums' where members of different cultural communities can meet and discuss differences in the hope of arriving at a tentative consensus. Parekh criticizes both Rawls ${ }^{9}$ and Habermas ${ }^{10}$ for making proposals that privilege rational deliberation cut off from the 'constitutive attachments' that make us who we are. ${ }^{11} \mathrm{He}$ consistently favors an understanding of humans deeply colored by one's 'cultural and evocative associations', noting that seemingly neutral topics of discussion can play out very differently for different groups owing to deep seated cultural assumptions, judgements and fears.

The manner in which Parekh arrives at moral judgements does not privilege either cultural or liberal principles. Instead, each situation calls for careful evaluation according to the degree that particular cultural practices enable a community to cohere and thrive, but also according to the degree that cultural practices discriminate against particular members of the community. Parekh admits that the process can be 'most exasperating' and is 'necessarily messy', but he insists that patience, sympathy and understanding are necessary to arrive at intercultural 
consensual agreements about morally acceptable cultural practice. Sometimes the arguments will run analogically, other times the basis will be universal values, and still other times an appeal might be made to a society's cultural or historical identity. ${ }^{12}$ Even where we might find certain cultural practices to be acceptable or unacceptable in themselves, they must be weighed against other, equally important, criteria including a culture's history, ethos, and traditions of inequality or power.

\section{The Difficulty of Equality}

Earlier I showed that for Parekh there can be no privileging of the monist position of universal values over the cultural. The opposite is of course equally true. Those who locate their interests on the side of the multiculturalist frequently invite the charge of relativist, while liberals stand accused of moral imperialism. But, liberals protest, without universal norms of some kind there is likely to be all manner of abuse toward weaker individuals in societies that privilege their own, self-contained body of values. Parekh agrees, but as I have shown, Parekh adamantly holds to the view that universal values must be seen in light of local, cultural values and interpreted accordingly. To illuminate his point I will take the liberal value of equality.

The value of equality can be articulated at a variety of levels. It entails equality of respect and rights, equality of opportunity, self-esteem, and self-worth, and finally it involves equality of power, well-being and the basic capacities required for human flourishing. Sensitivity at each of these levels is important and, Parekh points out, ' $[\mathrm{w}] \mathrm{e}$ can hardly be said to respect a person if we treat with contempt or abstract away all that gives meaning to his life and makes him the kind of person that he is' (ibid., p. 240). This means situating a person within her cultural background and its thought forms, but more importantly it also involves seeing one's opportunities in relation to others who comprise the dominant group. For example, while certain customs are defended based on a 'religious requirement,' many are little more than cultural expectations and can be suitably reinterpreted to fit different cultural and political norms. ${ }^{13}$ Other customs (e.g., narcotic use, abstention from pork), however, are more central to the way in which a cultural or religious group identifies itself. Equality, applied indiscriminately, will have different effects. Equal treatment cannot mean identical treatment. To indiscriminately apply the principle of equality will inevitably lead to injustice. Additional efforts are sometimes required in order to ensure that everyone is given an equal opportunity. ${ }^{14}$

For example, many people with physical or mental disabilities require additional assistance to attain the same (or, minimally, a higher) level of capability that others attain without effort. Similarly, there are those whose religious requirements necessitate special accommodation because to apply 'equality' across the board is to discriminate against certain groups and not others. Some accommodations may seem unreasonable and indeed, unfair. Certain cases (turbans for male Sikhs in the place of crash helmets) seem on the face of it to be a foolish compromise of safety sacrificed on the altar of cultural sensitivity. ${ }^{15}$ Others (sporting beards, yarmulkes, traditional dress, time off work for Friday prayers, etc.) will have to be negotiated in the intercultural space Parekh invites us to explore with respect, sensitivity and 
wisdom, recognizing that compromises will have to be made one way or another. He writes,

When we take legitimate cultural differences into account, as we should, equal treatment is likely to involve different or differential treatment, raising the question as to how we can ensure that the latter does not amount to discrimination or privilege. There is no easy answer to this. (ibid., p. 261)

Parekh is well aware that additional rights and resources can arouse anger and resentment among the majority group. Therefore, he insists that accommodations be granted only when they can be justified.

\section{Discussion}

Toward the beginning of this paper, I stated that Parekh commits three important errors. Having considered Parekh's general philosophical theory, I want to address each of these errors and proffer a few recommendations. (Here I must remind the reader that religion and culture, for Parekh, are inextricably linked.) To the point that religious persons should not be forced to segregate their private and public lives in order to engage in the political deliberative process, I will say three things. First, Parekh is right to ask us not to expect individuals to abstract away from their most cherished beliefs; multitudes of political players have labored for the public good according to the religious principles that inspire them. Parekh also makes an interesting case for including religious justifications in the political deliberative process; these include: (a) the idea that participating in a civic procedure ought to include some knowledge and understanding of the religious views many citizens hold; (b) the need to teach about religion in schools; and (c) learning about other ways of thinking facilitate 'a richer and [more] expansive conception of public reason'.

Nevertheless, it seems a serious mistake to extrapolate from the preceding points that religious justifications for public goods ought to be allowed, or that defending one's views in a language common to the public square 'discriminates against religious persons and violates the principle of equal citizenship' (ibid., p. 324). Parekh reasons that religious arguments create no more difficulties than the garden variety of secular arguments brandished for the deliberative process. I unreservedly disagree. It is one thing to say that the state ought to exempt certain individuals (e.g., Seventh-Day Adventists) from specific duties because they violate their religious integrity, or that the state ought to make certain provisions (e.g., military chaplains) to accommodate personal beliefs. However, it is another matter to equate the rights of freedom to follow one's conscience with religious justification, or to liken religion-inspired emancipatory movements with the grounds needed to achieve shared political values. Finding the common ground among 'reasonable persons" ${ }^{16}$ upon which agreements can be made and values pursued is a necessary goal; this is the positive side to dialogic consensus. However, I maintain that it is also necessary and desirable to sidestep the divisions that are likely to accompany exclusive claims to comprehensive religious truths. 
To illustrate how we might incorporate religious views into political deliberation, Parekh offers us the example of the Catholic Church, its position on abortion, and public policy. Parekh says that Catholics ought to be allowed to appeal to their religious dogmas in arguing against the practice. Yet, Parekh also notes why religious grounds for political justification depart from reasons that can appeal to the sympathies of non-adherents of that religion. Parekh beckons us to take up the criticisms of the Catholic Church on both internal and external grounds. His internal reasons are not terribly convincing and show his cursory knowledge of Catholic history and theology. His external arguments, however, are more compelling. He writes that while the Church may be allowed the freedom to express its views, it has no legal or moral right to use the machinery of the state to impose its views on those who disagree with it, and that:

... liberals are equally justified in imposing on [the Catholic Church] their own fundamental belief in the equality of the sexes ... [or] we might follow a different route and contend that since many communities do not welcome children born out of wedlock or have no means to support them, the Church must either provide a nationwide support system or refrain from making irresponsible and impossible demands. We could [also] reinforce the point by showing that unwanted children lack love, carry emotional scars [and] that banning abortion damages human dignity as much as and to an even greater degree than allowing it. (ibid., p. 326)

Parekh is ready to acknowledge the significant role that the Catholic Church can play in 'affirming an important value, nagging our consciences, [and] requiring us to reflect publicly and critically on our moral practices'. Nevertheless, he amply demonstrates why any religious counter arguments to this are doomed to failure, for no amount of patristic, encyclical or biblical exegesis is able to stand up to public scrutiny in this way. The reasons are obvious: justifications that rest on religious dogma are inaccessible and untenable to those who do not share the convictions to which they are attached. Parekh concedes the point but fails to see this as a reason to refrain from engaging citizens according to religious beliefs. ${ }^{17}$ Parekh needs to embrace more fully the manner in which liberalism accommodates a variety of ways of defining the good life (though not allowing for all definitions) without making explicit what those definitions must include. ${ }^{18}$ Autonomy is typically central to the liberal's concern, but as Eamonn Callan has argued, 'Autonomy is not the high road to all that is good nor is its absence a guarantee of evil' (Callan, 1997a, p. 49). More and more liberals are questioning the centrality of individual autonomy without jettisoning the incomparable freedom liberalism allows. Callan has eloquently stated that the objective of a sound liberal moral doctrine could not dictate the content of the good life 'in all its fine detail'. Liberals are averse to prescribing the particular ends of cultures or individual lives but do insist on a particular 'style or manner in which we should conduct our lives' (ibid., p. 18). If justice is to be procured, Callan writes,

A certain notion of reciprocity is the nerve of that virtue: the reasonable citizen is disposed to propose fair terms of cooperation to others, to settle 
differences in mutually acceptable ways, and to abide by agreed terms of cooperation so long as others are prepared to do likewise. Principles that pass the test of reciprocity under pluralism must abstract from many of the divisions that pluralism contains. (ibid., p. 175, emphasis added)

Enter now the second error that Parekh makes: he exaggerates the sense in which we are unalterably culturally embedded. I readily concede that the desire to remain affiliated to one's inherited culture usually remains strong, but it is another matter to insist that a person needs her culture to make meaningful decisions, or that one's autonomy is constrained within 'flexible but determinate limits'. That one might be so constrained is a matter for individual cases, but it is puzzling that Parekh, who finds the absolutizing tendencies of liberalism distasteful, seems to absolutize himself. Parekh needs to show us why it is that persons are unable or even disinclined-albeit to varying degrees-to relinquish their cultural template in favor of another (typically the freer one) in order to negotiate tough moral choices. ${ }^{19}$ The point is not whether most people leave the cultures into which they were born, but simply that some do, and many more move back and forth between two or more cultural milieus. One sees this repeatedly in immigrant communities, ${ }^{20}$ and cultural belonging is particularly problematic for parents who wrestle with intergenerational conflict where ethnicity and religion do not resonate with their children. Parekh's theory leaves little room for those who simply do not identify with their inherited culture and desire little if anything from it. ${ }^{21}$ Some individuals cannot exist, think, act or relate to others independent of their inherited cultural context but Parekh overstates his case when he extends this to everyone.

Further, to the point that the resources to criticize culture typically come from the inside, we might ask Parekh whether the internal critical resources he mentions can truly be summoned on pains of bodily harm, shunning, or death. In many cultures, reformers are constrained to draw upon religious texts in order to challenge power structures. If the rights to interpret religious texts rest with the clergy or its equivalent elite, prospects for authentic challenge are severely limited. Parekh admits that 'every culture is too multistranded, fluid and open-ended to have 'fixed terms' in which to evaluate it,' but this does little to console those who attempt to challenge community leaders who claim the right to define cultural norms for all members.

Parekh's discussion of the 'cosmopolitan' is also somewhat disparaging. It is disparaging because Parekh gives little recognition to the widespread hybrid identities of persons living in multicultural societies. Instead, we find him saying that these persons 'lack historical depth' and the resources to make meaningful choices. On this understanding, there is no recognition of the millions of individualsespecially immigrants-whose cultural identities daily overlap between two or more cultures. Parekh acknowledges that cultures 'constantly encounter one another,' challenge and borrow from one another widening their horizons and undergoing big and small changes (Parekh, 2000, p. 220). Nevertheless, in the main his discussion of culture, reformulated throughout his text, suggests a rigidity unamenable to hybrid identities. Jeremy Waldron explains the implausibility of this position: 
Most human lives are not led within the confines of a particular culture but are framed and formed both by the movements of people among cultures and by the movements of culture among peoples. Indeed the beginning of wisdom in multicultural education is the rejection of any simple correlation along the lines of 'one-person-one culture'. (Waldron, 2003, p. 26)

Ironically, Parekh's defense of diversity as an objective good seems an implicit endorsement of cosmopolitanism, and one has the feeling that his disdain for the cosmopolitan targets a bogeyman, most probably the dilettante, rather than those claiming more genuinely multi-cultural identities.

Parekh also seems unwilling to allow that the 'particular habits of thought' he attributes to cultural community need not be internalized. This is because he does not address the particular motives that accompany the 'habits of thought and feeling' that often accompany one's enculturation. Each of us, even the staunchest defenders of our culture, has qualms with certain customs, norms, prejudices or traits of temperament that hold sway over our respective communities. Each of us may be socialized into a particular manière d'être, but it does not follow that we are indelibly marked by it or even that we have internalized it. For many people, the habits of thoughts and feeling are governed less by internalized cultural principles and more by the logic of etiquette. Parekh is correct to say that each of us unconsciously acquires from our cultural communities bodily gestures, inhibitions, effortless communication and a 'body of sentiments and memories;' I also agree with his argument that well-being is enhanced on account of the traits within one's inherited community. However, it would be unwise to assume that these habits for many people are anything more than expedient-albeit culturally delineated-behaviors that facilitate familiar social intercourse. There is no doubt that one does share a sense of common identity with others by virtue of a measure of sameness that colors one's experiences in culturally distinctive ways. Even so, this identification may be very thin indeed. In societies where experiences are manifold, options seemingly endless, and issues dauntingly complex, Parekh's culturally circumscribed norms seem ill-equipped to grasp the manner in which millions of persons define themselves and negotiate moral choices by relativising their cultural norms. $\mathrm{He}$ also fails to distinguish between persons who choose to embrace or reject cultural values and those who have these elements imposed upon them.

Yet for all that I have said, Parekh's definition of culture is expansive enough to test his previous claims. First, he concedes that one's culture need not be defined by the culture into which one is born; rather, one's culture is 'the one we live, which has shaped us, and with which we identify'. Our lives are shaped and organized by influences that extend beyond our family background; indeed, Parekh writes that 'an ethnic community might lose its traditional culture, as when it migrates or abandons that culture in favour of another, [or] when it is freely adopted by or imposed on outsiders' (Parekh, 2000, p. 154). This will lead to a cultural community based on the attributes of a 'shared culture'. Furthermore, he is aware that cultures are fluid and that their participants regularly connect with 
other cultural communities through music, television, film and literature, not to mention daily contact through commerce. So here, we have the broader definition of culture that can satisfy the need of the cosmopolitan, but, given Parekh's assessment of the cosmopolitan, it is not at all clear how Parekh reconciles one with the other.

Finally, to the third point that Parekh conflates the cultural interests of the parents with those of the children, he assumes that children's interests will be identical to their parents'. So, on the question of the right to initiate one's children into a tradition through comprehensive religious schooling, Parekh gives parents his unreserved approval on the grounds that these schools:

... instill a distinct set of moral and cultural sensibilities, increase the available range of educational options, add to the variety of collective life by producing citizens with different characters and perspectives on life, respect the wishes of the parents, [and] prevent the state from acquiring the monopoly of education and exercising total control over its content ...'. (ibid., p. 133, emphasis added)

In order to rein in the problems that many are prepared to associate with a comprehensive religious education (i.e., a withdrawal from the broader purposes of citizenship), Parekh appeals to the vague requirements of a 'minimum nationally prescribed' curriculum. Yet, this tactic will doubtless alienate non-liberal communities who stand inflexibly opposed to these aims. Too, any concern for cultivating children's capacity to question their parents' culture or religion is simply not addressed. Parekh would appear to have it both ways, but his proposals will satisfy neither the liberal nor the multiculturalist. They will not satisfy the liberal because Parekh concedes too much to culture, even allowing for wholesale indoctrination of children. But neither will Parekh's proposals satisfy non-liberals because they too regard the openness of a liberal education as indoctrinatory, albeit in a relativist sense.

What we can deduce from Parekh vis-à-vis children is that his views appear to be congenial to parentalist liberals (though their liberalism has repeatedly been questioned). ${ }^{22}$ Insofar as children have specific interests, these liberals (inter alia Lomasky, Galston, Burtt) claim that they can only be interested in non-servility. ${ }^{23}$ These liberals resist the autonomy-promoting liberalism of others because of what they consider to be potentially oppressive requirements. Ensuring non-servility rather than autonomy also guarantees a certain amount of character-specific development that a character-neutral autonomy cannot. In other words, refusing to advance autonomy allows communities the space to cultivate other non-oppressive goods (e.g., obedience, loyalty, specified gender roles) considered central to wellbeing. (On the other hand, Callan points out that character-neutral autonomy will not suffice to loosen the habits that have taken root long ago in an individual's psyche and may have resulted in one's 'vulnerability to abuse'; see Callan, 1997b, p. 231.)

Parentalists view with considerable suspicion the push to make children autonomous. All choices, they argue, are conditioned (though not determined) choices. 
Loren Lomasky is representative of this view. He resolutely believes in the obduracy of human nature regardless of the totality of one's environmental conditioning. $\mathrm{He}$ writes,

... we all inherit ends from others and, contra the fervent champions of autonomy, it is good that we do so. Were that not the case, we would find our way barred to the formation of projects that essentially make the good of another a component of one's own good. (Lomasky, 1987, p. 184)

Parekh would sit well with Lomasky's view, I think, for even when he decries religious groups that seek to impose their views on others, refusing to accept their equality and respect their integrity, he does not have children in mind. Parekh would surely have something to say against unreasonable and intolerant views, but he appears to support the idea that parents are simply entitled to pass down their views to their children. Assuming that they are, it is doubtful whether Parekh recognizes the need to represent not only the child who exists today but also, in the words of Robert Noggle, the 'largely unknown future adult whom that child will become, and the moral community which she must join if she is to thrive and flourish' (Noggle, 2002, p. 115).

To the issue of religious schooling and the quandary it creates for potentially conflicting parent/child interests, there have been a number of attempts to reconcile liberal and communitarian/multicultural interests. Parekh has offered one of them, viz., the minimum nationally prescribed curriculum. He is too strong a believer in common citizenship to take leave of common schools and public institutions. Concerning religious schooling he has also said that they potentially hinder common and responsible citizenship 'unless they share a common curriculum and a common ethos, aim at broadly similar intellectual and moral virtues, and form part of a wellthought out educational framework' (Parekh, 1997, p. 527). Another approach has been to accept that early education might involve religious schooling in order to imbue children with cultural coherence before they engage with views outside of their community. ${ }^{24}$ A number of liberals have attempted to build this bridge. Take Meira Levinson:

... our conception of autonomy must incorporate a commitment to the development and preservation of cultural coherence. Individuals must be able to feel embedded within a culture or set of cultures, and to mediate their choices via the norms and social forms constitutive of their culture(s). (Levinson, 1999, p. 31, emphasis added)

Ultimately, however, the aim is to facilitate autonomy, a goal Levinson and other liberals unabashedly promote to the consternation of non-liberal communities. Liberals who favor diversity to a higher degree continually fall under the criticism that they make precious little provision for a meaningful exit from communities whose integrity they seek to defend. Parekh joins these liberals in seeking ways to close the divide between communitarian and liberal concerns. Yet while his unique contribution addresses the manner in which deliberation might take place-a collection of skills Parekh has doubtless garnered from his years in political office- the 
outcome of his proposals do not inspire confidence in the exhausting effort one must undertake.

\section{Conclusion}

Parekh grants that culture is not determinative of a person's identity. However, as I have tried to show in this paper, his insistence that we are culturally embedded leads him to posit that we have a duty to preserve our culture. This also leads him to reject cosmopolitanism and to opine that we need to have structured boundaries in order to make meaningful decisions. It is not clear whether Parekh can sustain the balance between, on the one hand, affirming the inherent good of diversity and the cultural embeddedness of individuals, and on the other hand the need to cultivate extensive sympathy with difference.

Of course Parekh is not alone in valuing diversity. While most liberals tend to hold an instrumental view of culture, increasingly liberals have given a primacy of place to cultural pluralism and have affirmed a variety of-even illiberal-ways of pursuing one's understanding of the good. These thinkers have been at pains to defend themselves against the charge of insensitivity to the needs of weaker members of cultures whose interests are not protected by the aims articulated by its leaders. Liberals often parade autonomy, rationality and freedom as the preeminent values to trump the 'unreasonable' demands of cultural communities. And, yet, it is precisely here that Parekh enters the debate. He joins the chorus of folks who hold liberals guilty of 'unreasonableness' insofar as they fail to provide reasons for prizing one set of (liberal) values over another. Whether liberals have failed to provide reasons for valuing these (but not only these) goods over the culturally circumscribed goods that challenge them is not a theme I will pursue here, but it is increasingly being addressed in the literature that facilitates the liberalcommunitarian debate.

I have argued that Parekh can be compared to Kymlicka, though they are different in at least two important ways: Parekh is more reluctant than Kymlicka to consider autonomy central to human well-being, and Parekh thinks revising one's views is unlikely to happen given the way culture so profoundly shapes all that we do. Parekh's strengths lie in his encouraging understanding through dialogue and reciprocal gesture, and by insisting that liberals not prejudge illiberal cultural norms prior to understanding the ways in which these cultures function and what goods obtain therein. Parekh also evinces powerful arguments pointing to the manifold ways in which individuals do not operate merely as free and rational agents but contextually as persons with distinctive histories, experiences and prejudices. Among his original contributions, Parekh demonstrates tenable reasons for taking religious persons seriously on their own terms (and even making provisions for laws that take account of communal libel).

Still, difficulties linger. We might ask Parekh: (1) in the process of fostering sympathy and understanding through intercultural dialogue, what assurances will there be that various cultures will loosen the reins on customs and traditions that guide the operations and activities of their members and resist 'dialogic consensus?' 
(2) If too much emphasis is placed on comparative evaluation, will there ever be sufficient justification-satisfactory to all parties-necessary to implement policies whose aims are to combat illiberal behaviors among minority groups? (3) Are we able to have confidence that dialogical consensus will give us the tools necessary to counter domestic abuses that pass for culture and are enshrined in religious belief? Parekh's theory, for all of its sophistication, confuses things (see Parekh, 2000 , pp. 146-47). If nothing else, there is reason to be concerned with his anthropological habit of linking too intimately the relationship between culture and religion, particularly when religious justifications too easily subsume cultural claims. Parekh is likely to respond that no assurances are available and risks will always attend political deliberations where neither side retains the upper hand. Even so, if persuasive argument is to be the tool of obtaining consensus, one can be sure that many groups that do not value persuasive reason-let alone human rightswill remain unmoved and obstinate to the values embraced by the majority. This is because different cultural groups exercise the freedom to value and practice different ideas of good, defined on their own terms. Because this is so, one has reason to fear a one-sided accommodation process with those who want nothing to do with the notions of equality, freedom, and autonomy as defined by liberalism. Indeed, his promotion of diversity as an objective good is precisely the sort of thing many illiberal communities will not dither to repudiate. These communities are unlikely to be coaxed away from their singular aims of indoctrination and insularity.

Let me be clear: I am not saying that liberalism ought to be imposed on all people irrespective of their wishes. Nevertheless, insofar as illiberal cultural groups are interested in sharing a social space respectfully with others, they are obliged to abide by certain standards of conduct. For example, one cannot, as recently happened in the Netherlands, call for the random killing of homosexuals simply because someone's personal belief system finds them repugnant. ${ }^{25}$ Illiberal groups are free to disagree with the terms set by liberal democracies but arguments against these terms must be made on publicly accessible grounds. Of course, groups may exempt themselves from engaging others in the public sphere with reasons accessible to others, but if they become unhappy with the manner in which state power is used against them, they will have little recourse in protesting it.

To his credit, Parekh is very mindful of this. He firmly believes in the equality of the sexes and seeks to avert 'irreversible harm' done to children. Yet, while he offers several case studies, there is no clear procedure for making qualitative judgements about certain cultural practices. ${ }^{26}$ In the end, equitable decisions will depend on a host of factors possibly leading us to the conclusion that even some questionable cultural practices need to be left alone. Furthermore, parental rights on Parekh's theory are left largely unchecked; this includes religious schooling for the purposes of instilling the values of the parents, a practice which receives his vigorous approval. While he supports a common curriculum that will strengthen civic virtues, these aims are kept to a minimum. By conferring parents with the right to educate their children as they see fit, Parekh ceases to apply his theory consistently when it is likely to matter the most. 
Parekh is committed to universalism, albeit a very thin one, but it is not liberalism. According to Tariq Modood,

Parekh is committed to [a] meta-ethical commitment to the cultural diversity that constitutes humanity, an understanding of humanity that eludes every culture but is glimpsed in the dialogue between cultures. (Modood, 2001, p. 247)

Even so, I believe Parekh is a closet liberal. Liberals know that insisting on certain universal values is sometimes the only recourse one has when faced with systematic discrimination that continues to be countenanced by 'culture'. Whatever its limitations, Parekh's theory offers us an inspiring example of how to approach seemingly intractable issues. Its foremost strength lies in his call to dialogue and mutual understanding. I agree with Parekh that only in dialogue should decisions be made concerning whether certain cultural practices ought or ought not to be accommodated. Parekh's theory also gives philosophical substance to the case for well-being in ways not narrowly defined by the criteria of liberals. The question remains, however, whether in light of the many illiberal communities who spurn the opportunity to learn from others, compromise, accommodation and a 'broad and inherently tentative consensus' fostered by dialogue and reciprocal gestures will ever thrive.

\section{Acknowledgement}

Thanks go to Harry Brighouse and Adam Nelson for useful suggestions and comments.

\section{Notes}

1. Parekh does not analytically distinguish culture from religion, arguing instead that '[r]eligion shapes a culture's system of beliefs and practices, [meaning that] culture influences how a religion is interpreted'. B. Parekh (2000) Rethinking Multiculturalism: Cultural Diversity and Political Theory (Cambridge, Cambridge University Press), p. 147.

2. Cultures are continually in the process of redefinition and reconstitution, though it is important to emphasize that cultural change-and the individual changes that occur with them-do not all occur at once or at the same speed. Some take place rather rapidly while others develop slowly and over a lifetime. Just as cultures are reconstituted, so too individual responses to culture self-modify and shift. Only where cultural changes occur too quickly or extensively to be absorbed by its members is there likely to be a crisis. This crisis may take the form of moral panic, reactionary resistance (often leading to fundamentalism of different sorts), and possibly profound individual conflict.

3. He does concede, however, that persons are not entirely bereft of certain 'speciesderived capacities,' by which he means ineliminable, independent resources and critical faculties.

4. See W. Kymlicka (1995) Multicultural Citizenship: A Liberal Theory of Minority Rights (Oxford, Oxford University Press), p. 171. Parekh disagrees with Kymlicka, correctly I think, on whether the distinction between national minorities and immigrant minorities matters so much (leading Kymlicka to argue that immigrants must assimilate as best they can), especially in light of Kymlicka's contention that culture is central to a person's well being. See B. Parekh, Rethinking Multiculturalism, op. cit., p. 103. 
5. Cf. W. Kymlicka (1989) Liberalism, Community and Culture (Oxford, Oxford University Press), p. 176.

6. Parekh prefers the liberalism of Joseph Raz on this point for his allowing well being a broader definition, not inextricably linked to autonomy. See J. Raz (1994) Ethics in the Public Domain: Essays in the Morality of Law and Politics (Oxford, Oxford University Press), pp. 155-176.

7. G. David, \& K. K. Ayouby (2002) Being Arab and Becoming Americanized: Forms of mediated assimilation in metropolitan Detroit, in: Y. Y. Haddad \& J. I. Smith (eds), Muslim Minorities in the West:Visible and invisible (Walnut Creek, CA, AltaMira), p. 140.

8. B. Parekh, op. cit., p. 251.

9. See J. Rawls (1993) Political Liberalism (Cambridge, Cambridge University Press), passim.

10. Parekh speaks admiringly of Habermas inasmuch as he calls upon twenty-first century citizens to look beyond strictly national identities to constitutional principles, but does not approve of Habermas' overly rational approach that takes no account of one's cultural or religious identity. See J. Habermas (1996) The European Nation-State: Its achievements and its limits. On the Past and Future of Sovereignty and Citizenship, in: G. Barakrishnan (ed.), Mapping the Nation, pp. 281-294.

11. The phrase is Michael Sandel's, an important influence on Parekh's thinking. See M. Sandel (1984) The Procedural Republic and the Unencumbered Self, Political Theory, 12:1, pp. 81-96.

12. This type of argument takes the form of showing parallels between one society and another. Thus to the question of bodily mutilation, Parekh draws attention to the fact that Western societies celebrate body piercing, tattoos and all kinds of cosmetic surgery (e.g. breast augmentation), much of which is extremely painful. Of course this does not speak to the problems of making analogous arguments, for instance whether such decisions to undergo willful disfigurement are free and rational.

13. This is the case, for instance, with the practice of ritual slaughter. Controversies have erupted throughout Europe over the Muslim practice of killing a fully conscious animal by slitting its throat. Most countries require that the animal be stunned first, but the controversy has not abated because religious purists invoke the 'religious duty' requirement. Parekh rides the fence here, and says that 'the pain lasting barely a few seconds should not be given greater moral weight than the cultural sentiments of the two communities'. He also adds that popular sensitivity to the rights of animals has not yet reached a point of intensity that we ought to consider the practice as morally offensive or disagreeable. He does, however, cite the case of Norway, where compromises have been made to suit the needs of the Norwegian government, popular sentiment, and the cultural requests of the Jewish and Muslim communities. See B. Parekh, op. cit., p. 274 .

14. In the United States, this is the logic behind the legislation of Title IX, American disabilities and affirmative action, all of which have been enacted to combat ways in which 'equality of opportunity' has played out in the United States. Positive forms of discrimination are justified repeatedly as a means of rectifying past injustices and furthering the aims of integration and equality.

15. Yet in the UK, acknowledging the additional responsibility incurred by those who insist on wearing turbans, Sikhs have reached a compromise with British officials and have agreed to assume a more personal responsibility on the occasion of injury. See Parekh's discussion, B. Parekh, op. cit., p. 243-249.

16. The expression is Rawlsian, I am aware, and there is much exception taken to it. Nevertheless, I use it here to describe a liberal aim that Parekh also appeals to without using this language. It is for this reason that I ultimately find Parekh to be a liberal.

17. One might cynically note that Parekh's proposals would likely discredit religion, but Parekh's culturally sensitive approach would disallow it. Moreover, there is too much good to any religious tradition to dismiss the entire religion. Parekh merely calls for 1) 
a discrediting of certain harmful cultural practices that enjoy the sanction of religion, and 2) the possibility for religious persons to appeal to their deepest convictions to buttress their claims in the public sphere.

18. Hence, those definitions that bring certain harm to a community's members ought not to be allowed.

19. This is precisely the case for lesbian Muslims, who are usually forced to either deny their sexual identities in order to conform to Islam, or abandon Islam in order to be true to their sexual identities. Very few (though there are some) attempt to wed the two seemingly irreconcilable cultures (one gay and the other ethnic/religious) together. The discussion took place on the PBS monthly magazine, In the Life, October 7, 2003.

20. This is exactly the theme taken up in O'Donnel's 2000 film, East is East.

21. This is made vividly manifest in the 2002 documentary film Devil's Playground, an intimate look at Amish teenagers who must choose during a rite of passage, referred to as Rumspringa, whether to remain within the community and be baptized members of the church. More than $10 \%$ decides to leave each year, never to return.

22. One's liberal status usually remains in tact when two criteria have been established: a) the theorist is ultimately concerned with the well being of individuals, and b) some authentic possibility of exiting the community into which one is born is provided.

23. Callan famously expounds this view, but already we find in Lomasky that servility is a vice.

24. See G. Snik \& J. de Jong (1995) Liberalism and Denominational Schools, fournal of Moral Education, 24, pp. 395-407; Cf. Callan (1997a) op. cit., p. 181. For a nice summary of these various attempts, see N. Burtonwood (2002) Political Philosophy and Lessons for Faith-based Schools, Educational Studies, 28:3, pp. 239-252.

25. The incident, recently carried in Dutch daily newspaper, describes the contents from a book, published by an Amsterdam mosque, in which an imam called for the death of homosexuals by throwing them off buildings headfirst. The Dutch government correctly sees this as beyond the limits of justifiable freedom and tolerance. See 'Gooi homo's van hoge gebouwen,' De Volkskrant (April 18, 2004).

26. This becomes obvious once one considers the very different outcomes of intercultural evaluation on various controversial cultural practices. Parekh walks us through several examples, but passes over the difficulty of adapted choices too quickly and fails to appreciate the potential violation of free will to the same degree in, say, arranged marriage that he does in the case of polygamy.

\section{References}

Burtonwood, N. (2002) Political Philosophy and Lessons for Faith-based Schools, Educational Studies, 28:3, pp. 239-252.

Callan, E. (1997a) Creating Citizens: Political Education and Liberal Democracy (Oxford, Oxford University Press).

Callan, E. (1997b) The Great Sphere: Education Against Servility, fournal of Philosophy of Education, 31:2, pp. 221-231.

David, G. \& Ayouby, K. K. (2002) Being Arab and Becoming Americanized: Forms of mediated assimilation in metropolitan Detroit, in: Y. Y. Haddad, \& J. I. Smith, (eds) Muslim Minorities in the West:Visible and invisible (Walnut Creek, CA, AltaMira), p. 140.

Habermas, J. (1996) The European Nation-State: Its achievements and its limits. On the past and future of sovereignty and citizenship, in: G. Barakrishnan (ed.), Mapping the Nation (London, Verso Books), pp. 281-294.

Kymlicka, W. (1995) Multicultural Citizenship: A Liberal Theory of Minority Rights (Oxford, Oxford University Press).

Levinson, M. (1999) The Demands of Liberal Education (Oxford, Oxford University Press). 
Lomasky, L. (1987) Persons, Rights, and the Moral Community (New York, Oxford University Press).

Modood, T. (2001) Their Liberalism and Our Multiculturalism? British fournal of Politics and International Relations, 3:2.

Noggle, R. (2002) Special Agents: Children's autonomy and parental authority, in: D. Archard and C. Macleod (eds), The Moral and Political Status of Children (Oxford, Oxford University Press), pp. 97-117.

Parekh, B. (1997) Managing Multicultural Societies, Round Table, 344.

Parekh, B. (1999) A Varied Moral World, in: S. Moller Okin, Is Multiculturalism Bad for Women? (Princeton, Princeton University Press).

Parekh, B. (2000) Rethinking Multiculturalism: Cultural diversity and political theory (Cambridge, Cambridge University Press).

Rawls, J. (1993) Political Liberalism (Cambridge, Cambridge University Press).

Raz, J. (1994) Ethics in the Public Domain: Essays in the morality of law and politics (Oxford, Oxford University Press).

Sandel, M. (1984) The Procedural Republic and the Unencumbered Self, Political Theory, 12:1.

Snik, G. \& de Jong, J. (1995) Liberalism and Denominational Schools, fournal of Moral Education, 24, pp. 395-407.

Waldron, G. (2003) Teaching Cosmopolitan Right, in: K. McDonough \& W. Feinberg (eds), Citizenship and Education in Liberal-Democratic Societies (Oxford, Oxford University Press), pp. 23-55. 